\title{
MSH6 germline mutations in early-onset colorectal cancer patients without family history of the disease
}

\author{
C Pinto', I Veiga', M Pinheiro', B Mesquita', C Jerónimo', O Sousa ${ }^{2}$, M Fragoso ${ }^{3}$, L Santos ${ }^{4}$, L Moreira-Dias ${ }^{5}$, \\ M Baptista ${ }^{6}$, C Lopes $^{7}$, S Castedo' and MR Teixeira ${ }^{*, 1}$ \\ 'Department of Genetics, Portuguese Oncology Institute, Porto, Portugal; ${ }^{2}$ Department of Radiotherapy, Portuguese Oncology Institute, Porto, Portugal; \\ ${ }^{3}$ Department of Oncology, Portuguese Oncology Institute, Porto, Portugal; ${ }^{4}$ Department of Surgery, Portuguese Oncology Institute, Porto, Portugal; \\ ${ }^{5}$ Department of Gastroenterology, Portuguese Oncology Institute, Porto, Portugal; ${ }^{6}$ Department of Surgery B, S. João Hospital, Porto, Portugal; \\ ${ }^{7}$ Department of Pathology, Portuguese Oncology Institute, Porto, Portugal
}

Germline MLHI and MSH2 mutations are scarce in young colorectal cancer patients with negative family history of the disease. To evaluate the contribution of germline MSH6 mutations to early-onset colorectal cancer, we have analysed peripheral blood of 38 patients diagnosed with this disease before 45 years of age and who presented no family history of hereditary nonpolyposis colorectal cancer-related cancers. Blood samples from 108 healthy volunteers were analysed for those genetic alterations suspected to affect the function of MSH6. Of the seven (18.4\%) MSH6 alterations found, we have identified three novel germline mutations, one 8 bp deletion leading to a truncated protein and two missense mutations resulting in the substitution of amino acids belonging to different polarity groups. High-frequency microsatellite instability was found in the patient with the MSH6 deletion, but not in the other 27 carcinomas analysed. No MLHI promoter methylation was detected in tumour tissue. Our findings suggest that germline MSH6 mutations contribute to a subset of early-onset colorectal cancer. Further studies are warranted to understand the genetic and environmental factors responsible for the variable penetration of $\mathrm{MSH6}$ germline mutations, as well as to identify other causes of early-onset colorectal cancer.

British Journal of Cancer (2006) 95, 752-756. doi:I0.1038/sj.bjc.66033। 8 www.bjcancer.com

Published online 29 August 2006

(c) 2006 Cancer Research UK

Keywords: MSH6; germline mutations; early-onset colorectal cancer

Germline mutations in mismatch repair (MMR) genes (mostly in MLH1 and MSH2) are associated with hereditary nonpolyposis colorectal cancer (HNPCC), a highly penetrant autosomal-dominant syndrome characterised by several affected individuals with colorectal cancer (CRC) or extracolonic tumours of the endometrium, stomach, small bowel, ureter, renal pelvis, ovary, and hepatobiliary tract (Lynch and de la Chapelle, 2003). Hereditary nonpolyposis colorectal cancer accounts for about $3-5 \%$ of all CRC, including a large proportion of those with a young age of diagnosis, representing the most common hereditary colon cancer syndrome (Petersen et al, 1999; Umar et al, 2004). Hereditary nonpolyposis colorectal cancer carriers are usually heterozygous for the mutant allele, retaining a functional copy of the gene that is apparently sufficient for DNA repair (Parsons et al, 1993). A subsequent somatic mutation, leading to inactivation of the wildtype allele, results in a mutator cancer phenotype named 'highfrequency microsatellite instability' (MSI-H), characterised by a high rate of base substitutions, as well as small insertions and deletions in mono- and dinucleotide repeats (Ionov et al, 1993). High-frequency microsatellite instability phenotype has also been reported in sporadic CRC $(10-15 \%)$, but somatic mutations in

*Correspondence: Professor MR Teixeira;

E-mail: mteixein@ipoporto.min-saude.pt

Received 6 March 2006; revised 18 July 2006; accepted 24 July 2006; published online 29 August 2006
MMR genes are rare in these cases (Peltomaki et al, 1993; Kuismanen et al, 2000; Kamory et al, 2003). MLH1 promoter region methylation, leading to silencing of this gene, is an alternative mechanism to mutation underlying MSI-H in sporadic CRC (Toyota et al, 1999). Genetic testing for hereditary predisposition is therefore critical for effective management of suspected HNPCC kindreds (de la Chapelle, 2004; Lynch et al, 2004; Hampel et al, 2005).

The identification of hereditary predisposition is not always easy based on clinical and familial data. Some CRC patients are diagnosed at a very young age, but do not show a family history of cancer indicative of HNPCC. The relative contribution of environmental and genetic factors for the development of the disease in this subset of patients is unknown, but previous investigations have shown that germline mutations in $M L H 1$ and MSH2 genes are scarce (Southey et al, 2005). MSH6 germline mutations have been mostly observed in atypical HNPCC families presenting a weaker family history, possibly caused by lower penetrance of mutations in this gene (Hendriks et al, 2004; Plaschke et al, 2004), and tumours in these families may be 'microsatellite stable', may present 'low-frequency microsatellite instability' (MSI-L), or may be MSI-H (Wu et al, 1999; Plaschke et al, 2000; Berends et al, 2002). We therefore aimed to evaluate the contribution of germline MSH6 mutations for early-onset CRC in patients without a family history of HNPCC-related cancer. 


\section{MATERIALS AND METHODS}

\section{Patients, samples, and DNA extraction}

After written informed consent, DNA was isolated from peripheral blood samples of 38 individuals who developed CRC before the age of 45 years and had negative family history of the disease (or other HNPCC-associated cancers; Table 1), using the salt-chloroform extraction method (Müllenbach et al, 1989). DNA extraction was also performed from paraffinembedded tumours available from 28 of the patients (Lungu

Table I Clinicopathologic features of the 38 early-onset CRC patients

\begin{tabular}{|c|c|c|c|c|}
\hline Patient & Gender & $\begin{array}{c}\text { Age at } \\
\text { diagnosis of } \\
\text { CRC (years) }\end{array}$ & Tumour location & $\begin{array}{l}\text { Family } \\
\text { history } \\
\text { of cancer }\end{array}$ \\
\hline । & $\mathrm{F}$ & 17 & Ascending colon & - \\
\hline 2 & $M$ & 27 & Ascending colon & - \\
\hline 3 & $M$ & 30 & Rectum/sigmoid colon & - \\
\hline 4 & $M$ & 33 & Sigmoid colon & - \\
\hline 5 & $\mathrm{~F}$ & 31 & Sigmoid colon & - \\
\hline 6 & $\mathrm{~F}$ & 42 & Rectum & - \\
\hline 7 & $\mathrm{~F}$ & 42 & Rectum & - \\
\hline 8 & $\mathrm{~F}$ & 34 & Rectum & Father: lung cancer \\
\hline 9 & $M$ & 19 & Rectum & - \\
\hline 10 & $\mathrm{~F}$ & 40 & Rectum & - \\
\hline | | & $\mathrm{F}$ & 38 & Sigmoid colon & - \\
\hline 12 & $M$ & 36 & Rectum & Father: lung cancer \\
\hline 13 & $\mathrm{~F}$ & 40 & Rectum & - \\
\hline 14 & $\mathrm{~F}$ & 30 & Rectum & - \\
\hline 15 & $\mathrm{~F}$ & 45 & Rectum & - \\
\hline 16 & $M$ & 39 & Rectum & - \\
\hline 17 & $\mathrm{~F}$ & 43 & Rectum & - \\
\hline 18 & $\mathrm{~F}$ & 45 & Sigmoid colon & - \\
\hline 19 & $M$ & 39 & Rectum & - \\
\hline 20 & $M$ & 45 & Rectum & - \\
\hline 21 & $M$ & 45 & Ascending colon & - \\
\hline 22 & $M$ & 31 & Rectum & - \\
\hline 23 & $M$ & 42 & Rectum & - \\
\hline 24 & $M$ & 38 & Ascending colon & - \\
\hline 25 & $\mathrm{~F}$ & 40 & Rectum & - \\
\hline 26 & $\mathrm{~F}$ & 32 & Ascending colon & - \\
\hline 27 & $M$ & 35 & Rectum & - \\
\hline 28 & $M$ & 35 & Rectum & - \\
\hline 29 & $M$ & 29 & Sigmoid colon & - \\
\hline 30 & $M$ & 31 & Rectum & - \\
\hline 31 & $\mathrm{~F}$ & 34 & Rectum & - \\
\hline 32 & $\mathrm{~F}$ & 39 & Rectum & - \\
\hline 33 & $M$ & 30 & Rectum & - \\
\hline 34 & $M$ & 38 & Sigmoid colon & - \\
\hline 35 & $\mathrm{~F}$ & 18 & Rectum & - \\
\hline 36 & $\mathrm{~F}$ & 36 & Rectum & - \\
\hline 37 & $\mathrm{~F}$ & 45 & Rectum & - \\
\hline 38 & $M$ & 42 & Rectum & - \\
\hline 39 & $\mathrm{~F}$ & 45 & Rectum/sigmoid colon & - \\
\hline
\end{tabular}

$\mathrm{CRC}=$ colorectal cancer; $\mathrm{F}=$ female; $\mathrm{M}=$ male. et al, 1992), as well as from peripheral blood of 108 healthy volunteers. The study was approved by the Institution Review Board.

\section{Screening for germline MSH6 mutations}

DNA from the 38 CRC patients were screened for MSH6 mutations by denaturing gradient gel electrophoresis (DGGE) using primers and conditions described previously (Wu et al, 1999). Exon 1 and the acceptor splice site of exon 10, as well as samples with abnormal DGGE patterns, were analysed by direct sequencing in an ABI PRISM 310 automatic sequencer using Big Dye Terminator Chemistry (Applied Biosystems, Foster City, CA, USA), according to the manufacturer's recommendations. Whenever necessary, exon 7 was resequenced using different set of primers to exclude or confirm the presence of a polymorphism at the initial primerannealing site (Kolodner et al, 1999).

\section{MSI analysis}

Of the 38 cases, DNA from 28 paraffin-embedded tumours and paired lymphocyte samples were evaluated for MSI. We analysed the Bethesda marker panel (Boland et al, 1998), which includes two mononucleotide repeats (BAT25 and BAT26) and three dinucleotide repeats (D2S123, D5S346, and D17S250). Another three mononucleotide repeat markers (BAT34C4, BAT-RII, and BAX) were also analysed, as MSI in MSH6 carriers has been mainly observed in this type of markers (Verma et al, 1999; Wijnen et al, 1999). DNA was amplified by PCR using fluorescence-labelled $5^{\prime}$ primers, as described previously (Oliveira et al, 1998; Zhou et al, 1998; Pyatt et al, 1999; Loukola et al, 2001), and analysed in an ABI PRISM 310 automatic sequencer. Cases were considered MSI-H when $\geqslant 30 \%$ of the markers were positive. The MSI-H case (see below) was routinely analysed for $M L H 1$ and $M S H 2$ germline mutations, using multiplex ligation-dependent probe amplification (MRC-Holland, Amsterdam), DGGE, and direct sequencing with primers and conditions described previously (Wu et al, 1997, 1998), and no pathogenic mutation was detected in these two genes.

\section{MLH1 promoter methylation analysis}

$M L H 1$ promoter methylation status was evaluated in MSI-positive cases (both MSI-H and MSI-L), using methylation-specific PCR with primers and conditions described by Fleisher et al (2001).

\section{RESULTS}

Seven of the 38 patients $(7 / 38 ; 18.4 \%)$ presented germline MSH6 changes (Table 2), six of them not described previously. One patient had the deletion c.3558_3565delTGAAAGTA (p.G1186fsX1190), two patients presented the missense mutations c.2633T >C (p.V878A) and c.3961A > G (p.R1321G), two patients had the silent mutations c.2272C $>$ T (p.L758L) and c.2319C > A

Table 2 MSH6 germline alterations (and respective MSI status) detected in 38 early-onset CRC patients and in healthy blood donors

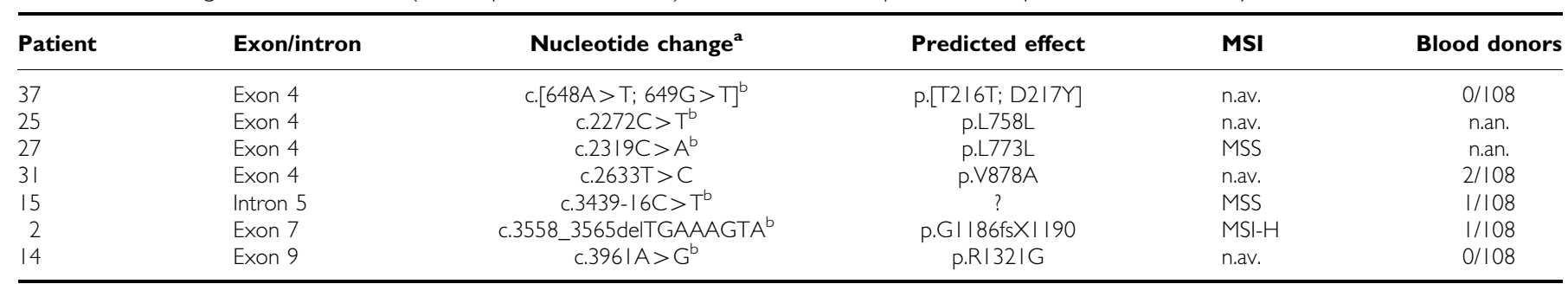

$\mathrm{CRC}=$ colorectal cancer; $\mathrm{MSI}=$ microsatellite instability; $\mathrm{MSI}-\mathrm{H}=$ high-frequency microsatellite instability; $\mathrm{MSS}=$ microsatellite stable; n.an. = not analysed; n.av. = not available. ${ }^{a}$ According to GenBank accession no. NM_000179, nucleotide numbering starts with the A of the start codon. ${ }^{b}$ Not described in the literature. 
(p.L773L), one patient showed the intronic alteration c.3439$16 \mathrm{C}>\mathrm{T}$, and another patient had a silent mutation and a missense mutation, c.[648A $>\mathrm{T} ; 649 \mathrm{G}>\mathrm{T}]$ (p.[T216T; D217Y]), in the same allele (Table 2).

In cases in which changes were suspected to affect the function of MSH6, namely, the deletion, the missense, and the intronic alterations, we looked for these nucleotide changes in blood samples from 108 healthy volunteers. The p.G1186fsX1190 and the c.3439-16C $>\mathrm{T}$ alterations were detected once and p.V878A in another two controls (Table 2). The p.G1186fsX1190 mutation was initially detected in apparent homozygosity (Figure 1) in the CRC patient and in the control using primers described by Wu et al (1999). Direct sequencing with additional primers demonstrated that these cases were in fact heterozygous for this mutation and that an insertion polymorphism in intron 7 located in the primerannealing region had not allowed the amplification of one allele with the initial set of primers (data not shown). The p.G1186fsX1190 mutation was subsequently identified in the healthy 54-year-old father of the proband (Figure 2).
High-frequency microsatellite instability and MSI-L was found in one and two of the 28 tumours, respectively. The MSI-H patient was positive only for the mononucleotide markers BAT25, BAT26, and BATRII and presented the p.G1186fsX1190 mutation. The two MSI-L patients were positive only for one marker and had no germline mutations in the MSH6 gene. None of these three cases showed $M L H 1$ promoter hypermethylation in the tumour (data not shown).

\section{DISCUSSION}

Molecular characterisation of early-onset CRC is important to clarify whether this clinical feature is caused by dominant germline mutations with variable penetrance or arising de novo, by recessive inheritance, or are merely sporadic events. Two groups have previously described one MSH6 germline mutation each in two young CRC patients without family history of the disease (Chan et al, 1999; Verma et al, 1999). We describe six previously
A

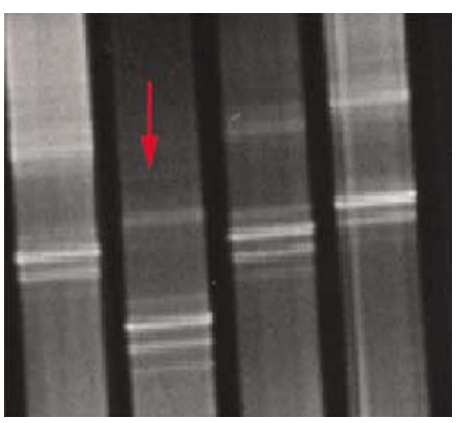

B

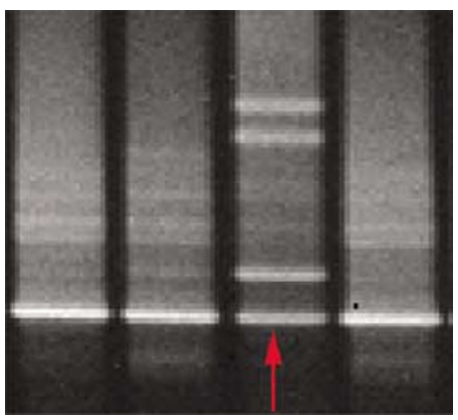

C

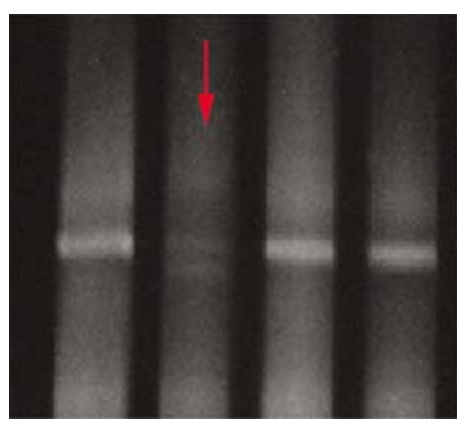

c.3558_3565delTGAAAGTA

p.G1186fsX1190

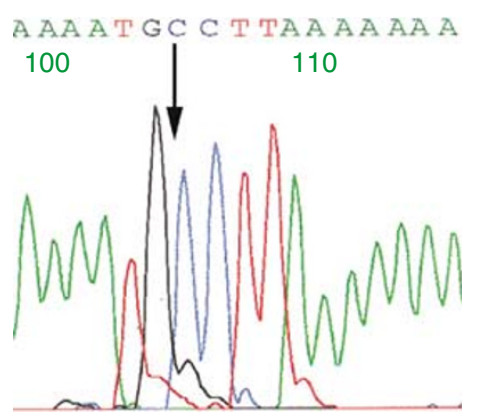

c. $[648 \mathrm{~A}>\mathrm{T} ; 649 \mathrm{G}>\mathrm{T}]$

p.[T216T; D217Y]

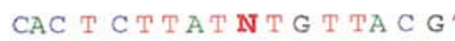

100

120
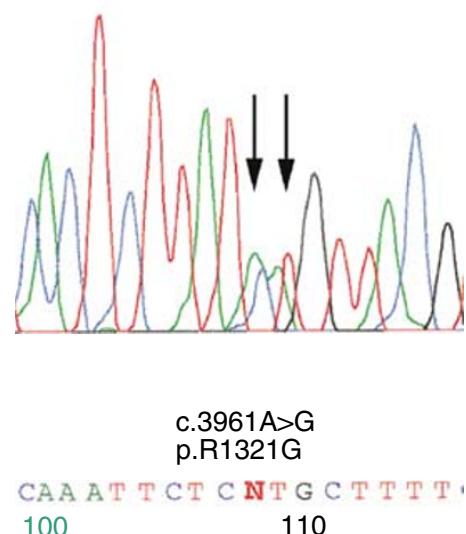

100

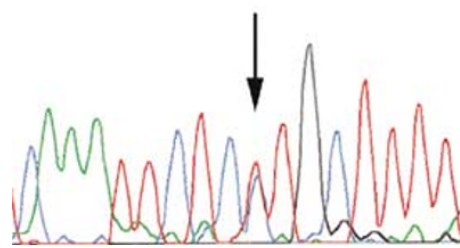

Normal

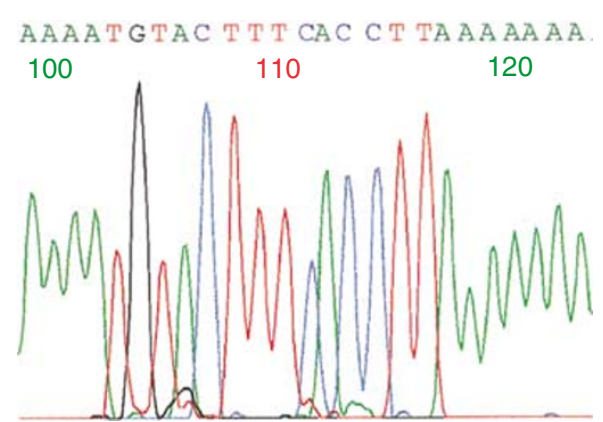

Normal

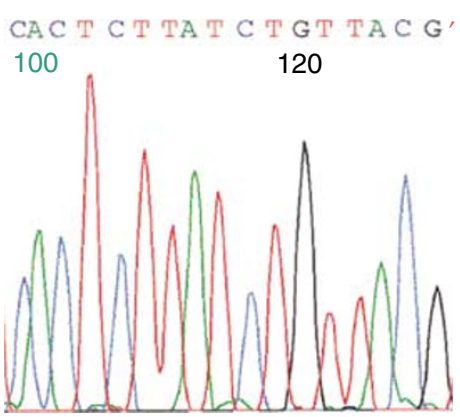

AA ATTCTCTTGC TTTTC'

$70 \quad 80$

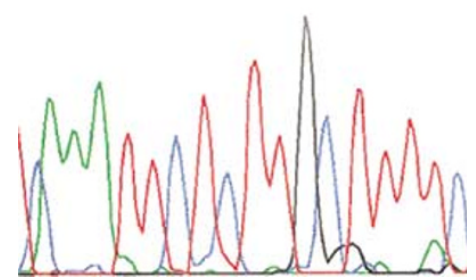

Figure I Possible disease-causing MSH6 mutations (arrows) identified in early-onset CRC patients. Denaturing gradient gel electrophoresis patterns and the nucleotide sequences (reverse) are shown for cases $2(\mathbf{A}), 37(\mathbf{B})$, and $14(\mathbf{C})$. Negative control sequences are shown to the right. 


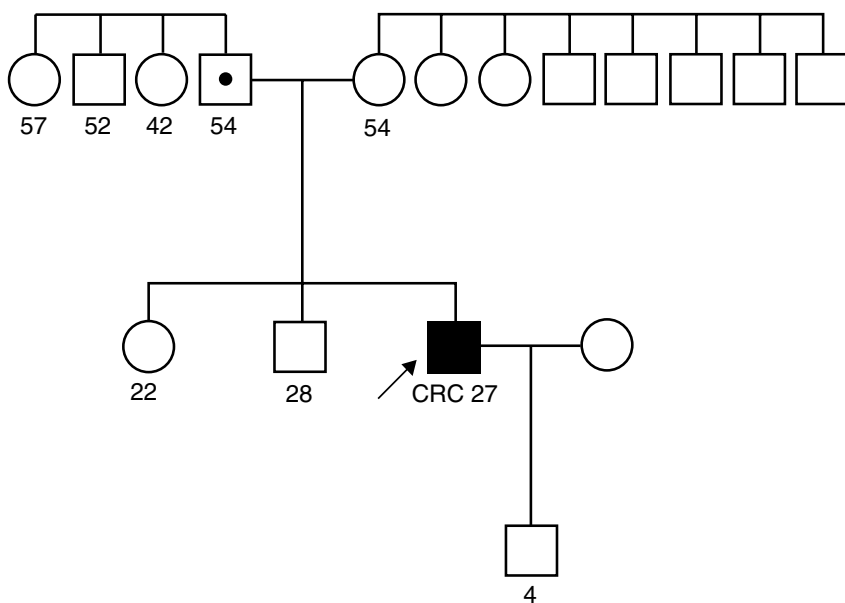

Figure 2 Family pedigree of patient nr. 2. Filled symbol (arrowed) represents the affected proband harbouring the heterozygous mutation p.GII86fs XI I90 and the symbol with a black circle represents a carrier. Numbers below the symbols indicate age at cancer diagnosis or age at last observation if unaffected. CRC: colorectal cancer.

unreported MSH6 genetic alterations in 38 early-onset CRC patients with negative family history of HNPCC-related cancer. Three of these six alterations are novel MSH6 germline mutations (three out of 38 mutations; 7.9\%), namely, a deletion and two missense mutations, one of the latter occurring contiguously to a silent mutation (Figure 1).

The MSH6 mutation p.G1186fsX1190 is in all likelihood disease causing, as it leads to a premature stop codon at position 1190 and the predicted truncated protein looses one of the two MSH2- and the $\mathrm{Mg}^{2+}$-binding domains (Kariola et al, 2002). In addition, the patient's tumour presented MSI-H phenotype only in mononucleotide markers, a feature reported to occur preferentially in tumours associated with MSH6 germline mutations (Verma et al, 1999; Wijnen et al, 1999), and screening for $M L H 1$ and $M S H 2$ mutations was negative. On the other hand, neither the 54-year-old father (Figure 2) nor the 47-year-old healthy blood donor carrying this mutation presented clinical symptoms of CRC (they had never performed colonoscopy screening), suggesting variable penetrance of this mutation. The modifier factors originating early-onset CRC in this 27-year-old patient remain unknown, but some data suggest that multiple mutations in different genes may influence the penetrance of the disease (Scheenstra et al, 2003; Soravia et al, 2005; Okkels et al, 2006). For instance, Okkels et al (2006) reported an 18-year-old CRC patient with three mutations (one missense $A P C$ mutation and a nonsense and a missense MSH6 mutation), whereas none of the family members presenting only one or two of the three mutations presented colorectal neoplasms. Other authors have suggested that genetic and environmental factors may modify the risk conferred by mutations in cancer predisposition genes, as considerable inter-individual variation in age at cancer diagnosis has been observed in kindreds sharing the same genetic predisposition mutation (Heinimann et al, 1999; Bala and Peltomaki, 2001). Further studies are warranted to identify factors modulating the age of onset, penetrance, or tumour location in individuals with inherited MMR deficiency, as this knowledge may improve risk estimates and help identify individuals who are genetically susceptible to develop CRC at an early age.

The two missense mutations that were not detected in the normal population (Figure 1) result in a substitution of amino acids belonging to different polarity groups. The mutation p.R1321G occurred in a highly conserved region of the gene, the MSH2-binding domain, suggesting that it would affect MSH6 protein function. The p.[T216T; D217Y] mutation, although not located in a functional domain, results in the substitution of a negatively charged amino acid for a non-polar amino acid that may cause abnormal MSH6 protein function. As these two genomic alterations are likely to alter the function of the protein and were not found in the control population, it is likely that they are pathogenic mutations, but functional studies will be necessary to determine how each of these MSH6 mutations affects protein function.

Besides the three presumably pathogenic mutations, we also identified three novel polymorphisms in the MSH6 gene: the two silent mutations p.L758L and p.L773L and the intronic alteration c.3439-16C $>$ T. On the other hand, the missense mutation p.V878A has previously been reported as a possible diseasecausing mutation by some investigators (Wijnen et al, 1999; ICGHNPCC database) and as a polymorphism by others (Peterlongo et al, 2003). Our finding of this alteration in the normal population corroborates that of Peterlongo et al (2003) and this change should now be classified as a polymorphism.

Of the 28 tumours that could be studied, MSI-H was found only in the case with MSH6 deletion. This tumour shows instability only in mononucleotide repeats, that is consistent with the higher incidence of MSI in this kind of markers in MSH6-deficient tumours described in the literature (Verma et al, 1999; Wijnen et al, 1999). The MSI-L phenotype has also been related to germline MSH6 mutations (Verma et al, 1999; Wijnen et al, 1999), but none of the two MSI-L tumours in this series showed MSH6 mutations or $M L H 1$ promoter hypermethylation. The biological basis of the MSI-L phenotype is currently under debate. This phenotype could result from alterations in MMR proteins other than MSH2 and MLH1, from defects in genes not directly involved in MMR, or it could simply represent a 'background' level of genetic instability that may be detectable in all tumours if a sufficient number of markers is analysed (Lengauer et al, 1998).

We conclude that germline MSH6 mutations contribute to a subset of early-onset CRC patients without a family history of the disease. Further studies are warranted to understand the genetic and environmental factors responsible for the variable penetration of these germline mutations and to identify other causes of earlyonset CRC, as this would help genetic counselling of these patients and their relatives.

\section{ACKNOWLEDGEMENTS}

We thank Dr Graça Varzim for the donor blood samples. This study was supported by Portuguese Health Ministry (Project No. 234/2001) and the Liga Portuguesa Contra o Cancro, Núcleo Regional do Norte.

\section{REFERENCES}

Bala S, Peltomaki P (2001) CYCLIN D1 as a genetic modifier in hereditary nonpolyposis colorectal cancer. Cancer Res 61: 6042-6045

Berends $M J$, Wu $Y$, Sijmons RH, Mensink RG, van der Sluis $T$, Hordijk-Hos JM, de Vries EG, Hollema H, Karrenbeld A, Buys CH, van der Zee AG, Hofstra RM, Kleibeuker JH (2002) Molecular and clinical characteristics of MSH6 variants: an analysis of 25 index carriers of a germline variant. Am J Hum Genet 70: 26-37

Boland CR, Thibodeau SN, Hamilton SR, Sidransky D, Eshleman JR, Burt RW, Meltzer SJ, Rodriguez-Bigas MA, Fodde R, Ranzani GN, Srivastava S (1998) A National Cancer Institute workshop on microsatellite instability 
for cancer detection and familial predisposition: development of international criteria for the determination of microsatellite instability in colorectal cancer. Cancer Res 58: 5248-5257

Chan TL, Yuen ST, Chung LP, Ho JW, Kwan KY, Chan AS, Ho JC, Leung SY, Wyllie AH (1999) Frequent microsatellite instability and mismatch repair gene mutations in young Chinese patients with colorectal cancer. J Natl Cancer Inst 91: 1221-1226

de la Chapelle A (2004) Genetic predisposition to colorectal cancer. Nat Rev Cancer 4: $769-780$

Fleisher AS, Esteller M, Tamura G, Rashid A, Stine OC, Yin J, Zou TT, Abraham JM, Kong D, Nishizuka S, James SP, Wilson KT, Herman JG, Meltzer SJ (2001) Hypermethylation of the hMLH1 gene promoter is associated with microsatellite instability in early human gastric neoplasia. Oncogene 20: 329-335

Hampel H, Frankel WL, Martin E, Arnold M, Khanduja K, Kuebler P, Nakagawa H, Sotamaa K, Prior TW, Westman J, Panescu J, Fix D, Lockman J, Comeras I, de la Chapelle A (2005) Screening for the Lynch syndrome (hereditary nonpolyposis colorectal cancer). N Engl J Med 352: 1851- 1860

Heinimann K, Scott RJ, Chappuis P, Weber W, Muller H, Dobbie Z, Hutter P (1999) N-acetyltransferase 2 influences cancer prevalence in hMLH1/ hMSH2 mutation carriers. Cancer Res 59: 3038 - 3040

Hendriks YM, Wagner A, Morreau H, Menko F, Stormorken A, Quehenberger F, Snadkuijl L, Moller P, Genuardi M, Van Houwelingen H, Tops C, Van Puijenbroek M, Verkuijlen P, Kenter G, Van Mil A, Meijers-Heijboer H, Tan GB, Breuning MH, Fodde R, Wijnen JT, Brocker-Vriends AH, Vasen H (2004) Cancer risk in hereditary nonpolyposis colorectal cancer due to MSH6 mutations: impact on counseling and surveillance. Gastroenterology 127: 17-25

ICG-HNPCC database [Online] [cited 2005 Jul 22]. Available from URL:http://www.insight-group.org.

Ionov Y, Peinado MA, Malkhosyan S, Shibata D, Perucho M (1993) Ubiquitous somatic mutations in simple repeated sequences reveal a new mechanism for colonic carcinogenesis. Nature 363: 558-561

Kamory E, Kolacsek O, Otto S, Csuka O (2003) hMLH1 and hMSH2 somatic inactivation mechanisms in sporadic colorectal cancer patients. Pathol Oncol Res 9: 236-241

Kariola R, Raevaara TE, Lonnqvist KE, Nystrom-Lahti M (2002) Functional analysis of MSH6 mutations linked to kindreds with putative hereditary non-polyposis colorectal cancer syndrome. Hum Mol Genet 11: 1303-1310

Kolodner RD, Tytell JD, Schmeits JL, Kane MF, Gupta RD, Weger J, Wahlberg S, Fox EA, Peel D, Ziogas A, Garber JE, Syngal S, Anton-Culver H, Li FP (1999) Germ-line msh6 mutations in colorectal cancer families. Cancer Res 59: 5068-5074

Kuismanen SA, Holmberg MT, Salovaara R, de la Chapelle A, Peltomaki P (2000) Genetic and epigenetic modification of MLH1 accounts for a major share of microsatellite-unstable colorectal cancers. Am J Patho 156: $1773-1779$

Lengauer C, Kinzler KW, Vogelstein B (1998) Genetic instabilities in human cancers. Nature 396: 643-649

Loukola A, Eklin K, Laiho P, Salovaara R, Kristo P, Jarvinen H, Mecklin JP, Launonen V, Aaltonen LA (2001) Microsatellite marker analysis in screening for hereditary nonpolyposis colorectal cancer (HNPCC). Cancer Res 61: 4545-4549

Lungu O, Wright Jr TC, Silverstein S (1992) Typing of human papillomaviruses by polymerase chain reaction amplification with $\mathrm{L} 1$ consensus primers and RFLP analysis. Mol Cell Probes 6: 145-152

Lynch HT, de la Chapelle A (2003) Hereditary colorectal cancer. N Engl J Med 348: 919-932

Lynch HT, Riley BD, Weissman SM, Coronel SM, Kinarsky Y, Lynch JF, Shaw TG, Rubinstein WS (2004) Hereditary nonpolyposis colorectal carcinoma (HNPCC) and HNPCC-like families: Problems in diagnosis, surveillance, and management. Cancer 100: $53-64$

Müllenbach R, Lagoda PJ, Welter C (1989) An efficient salt-chloroform extraction of DNA from blood and tissues. Trends Genet 5: 391

Okkels H, Sunde L, Lindorff-Larsen K, Thorlacius-Ussing O, Gandrup P, Lindebjerg J, Stubbeteglbjaerg P, Oestergaard JR, Nielsen FC, Krarup HB (2006) Polyposis and early cancer in a patient with low penetrant mutations in MSH6 and APC: hereditary colorectal cancer as a polygenic trait. Int J Colorectal Dis (E-pub ahead of print, doi 10. 1007/s003841006-0086-9)

Oliveira C, Seruca R, Seixas M, Sobrinho-Simoes M (1998) The clinicopathological features of gastric carcinomas with microsatellite instability may be mediated by mutations of different 'target genes': a study of the TGFbeta RII, IGFII R, and BAX genes. Am J Pathol 153: $1211-1219$
Parsons R, Li GM, Longley MJ, Fang WH, Papadopoulos N, Jen J, de la Chapelle A, Kinzler KW, Vogelstein B, Modrich P (1993) Hypermutability and mismatch repair deficiency in RER+ tumor cells. Cell 75: 1227-1236

Peltomaki P, Lothe RA, Aaltonen LA, Pylkkanen L, Nystrom-Lahti M, Seruca R, David L, Holm R, Ryberg D, Haugen A (1993) Microsatellite instability is associated with tumors that characterize the hereditary nonpolyposis colorectal carcinoma syndrome. Cancer Res 53: 5853-5855

Peterlongo P, Nafa K, Lerman GS, Glogowski E, Shia J, Ye TZ, Markowitz AJ, Guillem JG, Kolachana P, Boyd JA, Offit K, Ellis NA (2003) MSH6 germline mutations are rare in colorectal cancer families. Int J Cancer 107: $571-579$

Petersen GM, Brensinger JD, Johnson KA, Giardiello FM (1999) Genetic testing and counseling for hereditary forms of colorectal cancer. Cancer 86: $2540-2550$

Plaschke J, Engel C, Krüger S, Holinski-Feder E, Pagenstecher C, Mangold E, Moeslein G, Schulmann K, Gebert J, von Knebel Doeberitz M, Rüschoff J, Loeffler M, Schackert HK (2004) Lower incidence of colorectal cancer and later age of disease onset in 27 families with pathogenic MSH6 germline mutations compared with families with MLH1 or MSH2 mutations: the german hereditary nonpolyposis colorectal cancer consortium. J Clin Oncol 22: 4486-4494

Plaschke J, Kruppa C, Tischler R, Bocker T, Pistorius S, Dralle H, Ruschoff J, Saeger HD, Fishel R, Schackert HK (2000) Sequence analysis of the mismatch repair gene hMSH6 in the germline of patients with familial and sporadic colorectal cancer. Int J Cancer 85: 606-613

Pyatt R, Chadwick RB, Johnson CK, Adebamowo C, de la Chapelle A, Prior TW (1999) Polymorphic variation at the BAT-25 and BAT-26 loci in individuals of African origin. Implications for microsatellite instability testing. Am J Pathol 155: 349-353

Scheenstra R, Rijcken FE, Koornstra JJ, Hollema H, Fodde R, Menko FH, Sijmons RH, Bijleveld CM, Kleibeuker JH (2003) Rapidly progressive adenomatous polyposis in a patient with germline mutations in both the APC and MLH1 genes: the worst of two worlds. Gut 52: 898-899

Soravia C, DeLozier CD, Dobbie Z, Berthod CR, Arrigoni E, Brundler MA, Blouin JL, Foulkes WD, Hutter P (2005) Double frameshift mutations in APC and MSH2 in the same individual. Int J Colorectal Dis 20: 466-470

Southey MC, Jenkins MA, Mead L, Whitty J, Trivett M, Tesoriero AA, Smith LD, Jennings K, Grubb G, Royce SG, Walsh MD, Barker MA, Young JP, Jass JR, St John DJ, Macrae FA, Giles GG, Hopper JL (2005) Use of molecular tumor characteristics to prioritize mismatch repair gene testing in early-onset colorectal cancer. J Clin Oncol 23: 6524-6532

Toyota M, Ahuja N, Ohe-Toyota M, Herman JG, Baylin SB, Issa JP (1999) CpG island methylator phenotype in colorectal cancer. Proc Natl Acad Sci USA 96: $8681-8686$

Umar A, Risinger JI, Hawk ET, Barrett JC (2004) Testing guidelines for hereditary non-polyposis colorectal cancer. Nat Rev Cancer 4: 153-158

Verma L, Kane MF, Brassett C, Schmeits J, Evans DG, Kolodner RD, Maher ER (1999) Mononucleotide microsatellite instability and germline MSH6 mutation analysis in early onset colorectal cancer. J Med Genet 36: $678-682$

Wijnen J, de Leeuw W, Vasen H, van der Klift H, Moller P, Stormorken A, Meijers-Heijboer H, Lindhout D, Menko F, Vossen S, Moslein G, Tops C, Brocker-Vriends A, Wu Y, Hofstra R, Sijmons R, Cornelisse C, Morreau H, Fodde R (1999) Familial endometrial cancer in female carriers of MSH6 germline mutations. Nat Genet 23: $142-144$

Wu Y, Berends MJ, Mensink RG, Kempinga C, Sijmons RH, van Der Zee AG, Hollema H, Kleibeuker JH, Buys CH, Hofstra RM (1999) Association of hereditary nonpolyposis colorectal cancer-related tumors displaying low microsatellite instability with MSH6 germline mutations. Am J Hum Genet 65: $1291-1298$

Wu Y, Hayes VM, Osinga J, Mulder IM, Looman MW, Buys CH, Hofstra RM (1998) Improvement of fragment and primer selection for mutation detection by denaturing gradient gel electrophoresis. Nucleic Acids Res 26: $5432-5440$

Wu Y, Nystrom-Lahti M, Osinga J, Looman MW, Peltomaki P, Aaltonen LA, de la Chapelle A, Hofstra RM, Buys CH (1997) MSH2 and MLH1 mutations in sporadic replication error-positive colorectal carcinoma as assessed by two-dimensional DNA electrophoresis. Genes Chromosomes Cancer 18: $269-278$

Zhou XP, Hoang JM, Li YJ, Seruca R, Carneiro F, Sobrinho-Simoes M, Lothe RA, Gleeson CM, Russell SE, Muzeau F, Flejou JF, Hoang-Xuan K, Lidereau R, Thomas G, Hamelin R (1998) Determination of the replication error phenotype in human tumors without the requirement for matching normal DNA by analysis of mononucleotide repeat microsatellites. Genes Chromosomes Cancer 21: 101-107 